DOI: $10.17805 /$ zpu.2016.2.20

\title{
Политические проекты казанского дворянства в 1905 г. как новая ступень самосознания
}

\author{
Е. В. МИРОНОВА \\ (ИНСТИТУТ ИСТОРИИ ИМ. Ш. МАРДЖАНИ АКАДЕМИИ НАУК \\ РЕСПУБЛИКИ ТАТАРСТАН, Г. КАЗАНЬ)
}

В статье рассматривается тема участия членов Казанского губернского дворянского собрания в составлении проектов государственного устройства Российской империи в сложный политический период 1905 г. Данная проблема представляет актуальность в свете повышенного внимания к вопросам парламентаризма и самоуправления.

На материалах журналов Казанского губернского дворянского собрания и трудов комиссии по вопросу о народном представительстве показано, что разработка проектов устройства представительного органа в Казанском губернском дворянском собрании началась с целью успокоения волнений в обществе, особенно среди крестьян. Разработка велась по двум направлениям: на основе профессионально-классовой избирательной системы и на основе всеобщего равного избирательного права. Сторонники всеобщих равных выборов отличались большей демократичностью, однако они не учитывали величину избирательных округов и отсутствие культуры демократических выборов среди населения России. Члены комиссии поддержали первый проект и проголосовали за наделение представительного органа правом законодательной инициативы. В дальнейшем, после всероссийского дворянского съезда, А.Н. Боратынским и В. В. Марковниковым была предложена альтернатива в виде территориально-земского избирательного начала, согласно которому депутатов должны были избирать земства.

Документы показывают, что дворянская корпорация не была единой и делилась на умеренно монархическое, правое и либеральное крылья. Разработка проектов велась лишь крупнопоместным дворянством, которое желало внести успокоение в общество и осознанно относилось к решению не только местных вопросов, но и общероссийских проблем. Хотя труды казанской комиссии в дальнейшем и не были представлены в «булыгинскую комиссию", но подобная работа способствовала вовлечению местных дворян в общероссийскую политическую жизнь.

Исследование показывает, что пути становления парламентаризма в России были весьма извилисты и даже в рамках одной социальной группы существовали значительные противоречия по поводу политического устройства страны. Победу одержали сторонники сословной системы выборов, поскольку это позволяло дворянам быть более представленными в будущей Думе, чем при других системах. В дальнейшем идеи этих проектов во многом послужили основой для консолидации дворянства и развития дворянского самоуправления.

Ключевые слова: история России; Российская империя; Казанская губерния; первая российская революция; дворянство; Государственная дума; народное представительство 
ВВЕАЕНИЕ

Политическая деятельность дворян Казанской губернии в период революции 1905-1907 гг. частично затронута в работах А. В. Хабибрахмановой (Хабибрахманова, 2006), А. М. Айнутдиновой и Р. А. Айнутдинова (Айнутдинова, Айнутдинов, 2012), А. М. Усмановой (Усманова, 2006), Е. В. Мироновой (Миронова, 2013), но вопрос о разработке проектов устройства представительного органа в Казанском губернском дворянском собрании в литературе практически не поднимался. Между тем это был совершенно новый вид деятельности для высшего сословия губернии, знаменующий переход от решения местных проблем к всероссийской политической деятельности. Поэтому данная проблема имеет большое значение для изучения как сословного самоуправления, так и российского парламентаризма.

Соответственно, цель статьи обозначается нами как изучение взглядов казанского дворянства на будущее устройство представительного органа Российской империи. Аля этого нам необходимо узнать причины и цели составления таких проектов, понять, выступало ли дворянство единым целым в подаче таких проектов или же у них были разногласия. Аля решения данных задач мы использовали метод типологизации, который позволил разбить проекты и политические взгляды дворян на группы, и метод сравнения, чтобы проанализировать сходства и различия этих групп.

\section{ПОАИТИЧЕСКАЯ АКТИВИЗАЦИЯ АВОРЯНСТВА}

Революция 1905-1907 гг. принесла в Казанскую губернию не только волнения и взрывы насилия, но и значительно активизировала население в политическом отношении. Причем этот процесс затронул как низшие слои, так и тех, кто находился на вершине социальной лестницы. Аворянство, отчасти напуганное поднявшимся движением, отчасти осознавая необходимость политических реформ, принялось искать выход из сложившейся ситуации не только на местном уровне, но и на общегосударственном.

Высочайший рескрипт на имя министра внутренних дел А. Н. Булыгина от 18 февраля 1905 г. и последующие нормативно-правовые акты 1905 г. (Манифест 6 августа об учреждении Государственной думы, Манифест 17 октября об усовершенствовании государственного порядка) активизировали общественно-политическую деятельность дворянских обществ всех территорий Российской империи, приступивших к немедленному рассмотрению данных документов и выработке собственных предложений, основное внимание в которых было уделено принципам формирования нового учреждения. В Казанской губернии дворянство провело внеочередной съезд менее чем через месяц после объявления рескрипта.

Первоначально собрание созывалось лишь для принесения благодарности государю за указ, но дворянин К. А. Юшков, по выражению члена собрания С. В. Аьяченко, «загипнотизировал» дворянство своими речами о необходимости объединения дворянства, чтобы остановить аграрное движение, уже начавшееся на юге страны и грозившее всему отечеству (речь идет о массовых крестьянских выступлениях, происходивших в Харьковской, Полтавской и других южных губерниях в 1905 г.) (Журналы ..., 1906: 18). Поэтому повестка была расширена вопросами об избрании комиссии, которая бы определила способ выбора делегатов в будущую Государственную думу. Таким образом, одной из главных причин, заставивших дворянство приступить к обсуждению политических вопросов, стал страх перед крестьянскими волнениями. 
Было создано две подкомиссии, одна из которых рассматривала вопрос об избрании народного представительства на профессионально-классовой основе, а другая на принципе всеобщего равного избирательного права.

\section{ПРОЕКТЫ ПРОФЕССИОНААЬНО-КААССОВОЙ \\ СИСТЕМЫ ВЫБОРОВ}

Первая подкомиссия основывалась на проекте профессора Казанского университета В. В. Ивановского. Проект предусматривал двухпалатную Ауму, нижняя палата которой состоит из представителей от земледелия, промышленности и торговли, от ремесел и рабочего класса, от свободных профессий, чиновников и духовенства и от окраин, избираемых по указанным классам отдельно, и предусматривал определенный имущественный ценз для избирателей. В состав верхней палаты входили в основном лица по назначению монарха, она избиралась на шесть лет, через каждые три года половина выборных членов обновлялась (Проект ..., 1905: 1).

По данному проекту активное избирательное право предоставлялось русским подданным мужского пола, достигшим 25 лет, умеющим читать или писать по-русски или на своем языке, получающим доход не менее 100 руб. в год или имеющим свой дом либо уплачивающим прямые налоги не менее 5 руб. в год и живущим в губернии или области не менее одного года. Аля желающих быть избранными в Ауму возрастной ценз повышался до 30 лет. Будущий депутат должен был иметь образование не ниже среднего (для земледельцев, ремесленников и рабочих - не ниже начального училища), годовой доход не менее 600 руб., уплачивать налог не менее 20 руб. или квартирный налог не менее 5 руб. в год, а также жить в губернии не менее года (там же: 2). Aля земледельческой группы ввиду ее многочисленности выборы были двухстепенными, один выборщик избирался от 500 человек. Аругие группы выбирали депутатов непосредственно.

При дальнейшей проработке проекта в подкомиссии он был слегка изменен. В частности, вместо разделения по группам, предложенного Ивановским, было утверждено следующее: 1) группа частного землевладения; 2) группа землевладения общего и подворного; 3) торгово-промышленная группа; 4) группа рабочих; 5) группа городского населения (Протокол ..., 1905: 2). Выделение частных землевладельцев в отдельную группу отвечало интересам помещиков, а исчезновение «окраинных» депутатов отвечало устремлениям консервативных дворян, входивших в подкомиссию. Поскольку В. В. Ивановский был профессором университета, постольку, видимо, позиционировал себя именно с этой стороны, когда включал в свой проект группу от свободных профессий, чиновников и духовенства. Основная же часть дворянства рассматривала себя как землевладельцев, решив, что представители данных слоев общества смогут войти в Ауму в составе других групп.

\section{ПРОЕКТЫ ВСЕОБЩЕЙ ИЗБИРАТЕАЬНОЙ СИСТЕМЫ}

Во вторую подкомиссию представили проекты А. В. Васильев, М. М. Хвостов и В. Н. Ивановский. Все трое были профессорами Казанского университета и придерживались либеральных взглядов. В этих проектах, которые были сведены в один, не было имущественного и образовательного ценза, разделения по сословиям и классам, в будущем предполагалось прямое голосование, но, учитывая определенные трудности, на два-три срока предлагалось ввести двухстепенные выборы (Записка ..., 1905: 3). Аепутаты должны были лишь уметь читать и писать по-русски (там же: 2). 
Согласно этому документу выборы проходили бы по территориальному принципу. Каждый уезд, каждый губернский город и каждый город с населением свыше 50 тыс. человек должны были составлять особый избирательный округ. В каждом избирательном округе избирался бы один депутат (там же: 3 ).

Большинство голосовавших высказалось за избрание уполномоченных на началах профессионально-классового избирательного права. По вопросу о правах и функциях представительства были приняты резолюции о праве законодательной инициативы с утверждением монархом, полном контроле над финансовым хозяйством страны и контроле над законностью действий администрации (Постановления ..., 1905: 10). Помимо того, было принято решение о включении в состав создававшегося органа крестьян, свободно избранных ими самими.

Труды дворянской комиссии предназначались для известной комиссии А. Г. Булыгина ${ }^{1}$, работавшей с февраля по июль 1905 г., но собрание приступило к разбору трудов только в июне, когда «булыгинская комиссия» практически окончила свою работу. В итоге они послужили основой для разработки программы депутату от губернского дворянского собрания на общероссийский дворянский съезд 12 июня 1905 г. в Петербурге.

Нужно отметить, что это была позиция незначительной части казанского дворянского общества, поскольку к разработке темы, а затем и к голосованию по ней были допущены дишь крупнопоместные дворяне (Журналы ..., 1906: 12, 15). Им же предстояло избрать из своей среды делегатов на всероссийский дворянский съезд в Москве, назначенный на 24 апреля 1905 г. Аелегатами стали А. П. Арцыбашев, В. В. Марковников и А. Н. Боратынский (Отчет ..., б. г: 6).

\section{ПОАИТИЧЕСКАЯ АИФФЕРЕНЦИАЦИЯ КАЗАНСКОГО АВОРЯНСТВА}

По возвращении их из Москвы в Казани было созвано чрезвычайное дворянское собрание. Взгляды членов губернского дворянства относительно характера проведения выборов в представительный орган претерпели значительные изменения. Князь А. А. Кропоткин призывал обратиться к идее соборности, когда все «вне зависимости от сословий и положений будут самоуравниваться во имя правды» (Журналы ..., 1906: 23). Схожую точку зрения высказал А. И. Якобий, пожелавший возродить Земский собор, результатом чего, по его мнению, должны были стать «соединенные Русско-Славянские штаты» (там же: 25). А. А. Корсаков полагал, что в представительстве должна учитываться не только сословная принадлежность, но и национальность (там же). А. Н. Боратынский и В. В. Марковников представили отдельное мнение по этому вопросу: «По нашему убеждению, в основание организации народного представительства должно быть положено исторически развивающееся в нашем государстве земское начало...» (Боратынский, Марковников, б/г.: 2).

В итоге расклад голосов был следующий: за земскую губернскую систему высказались 47 дворян против 55, за сословную - 63 против 26, за всеобщую, равную, прямую и тайную - 15 против 77 (Журналы ..., 1906: 30). Налицо был численный рост сторонников сословного принципа при незначительном увеличении, по сравнению с предыдущим голосованием, приверженцев территориального. Одновременно обозначилась группа голосовавших за демократические выборы (там же).

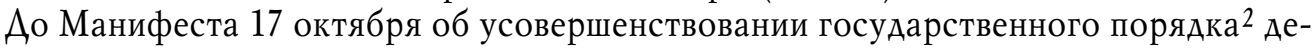
ятельность дворян состояла в обсуждении будущего устройства Аумы и давлении на 
правительство с целью скорейшего созыва народного представительства. Однако затеянное с размахом составление проектов по устройству парламента не получило должного воплощения Но в ходе обсуждений проявились политические воззрения разных групп дворян. Те, кто высказывались за профессионально-классовую и земскую системы выборов, представляли собой умеренно монархическое и правое крыло дворянства, а сторонники всеобщих, прямых и равных выборов в основном были либерально настроенными дворянами. К первым можно отнести П. И. Геркена, А. Н. Боратынского, В. В. Молоствова, М. И. Аогеля, ко вторым - В. П. Куприянова, А. В. Васильева, В. Н. Ивановского.

Интересна аргументация той и другой стороны. Профессор Васильев считал, что право всеобщего и равного голосования приучает граждан к мысли, что решение волнующих вопросов нужно искать, не прибегая к грубой силе. Поэтому он отвергает цензовое и групповое представительство. Критикуя профессионально-классовую систему выборов, Васильев приводит распространенное мнение, что при ней народные представители являются народными только по имени, на деле же они - представители определенных экономических интересов (Право ..., 1905: 4).

Противники всеобщего избирательного права опасались, что оно может отдать народную массу в руки профессиональных политиканов, а также того, что из-за большой величины избирательных округов избиратели не будут лично знать, кого они выбирают (Протокол ..., 1905: 1).

\section{ЗАКАЮЧЕНИЕ}

Причинами, побудившими казанских землевладельцев заняться «большой» политикой, с одной стороны, был страх перед революционным движением, особенно аграрными беспорядками, с другой - многие дворяне понимали, что необходимы политические реформы и руководствовались желанием принести пользу стране. Политически активной была лишь верхушка казанского дворянства, которая не могла просто переждать революцию без потерь, но которая также обладала и чувством ответственности перед обществом, неся службу как в органах дворянского, так и земского самоуправления. Но и взгляд крупнопоместных дворян на будущее устройство страны не был единым. Одни считали, что лишь демократизация способна внести успокоение в общество, другие призывали быть более ответственными и не доверять управление огромным государством голословным политикам, обещаниям которых может довериться народ. Некоторые дворяне, такие как профессора А. В. Васильев и В. В. Ивановский, основывали свои взгляды на теоретических построениях, другие, как Н. А. Боратынский, - на опыте местного самоуправления, но Государственная дума была совершенно новым институтом, и практического опыта не было ни у кого. В ходе работы над проектами местное дворянство перешло на новый этап политического самосознания: расширило свой кругозор, вышло за рамки местных интересов и включилось в общероссийскую политическую жизнь.

На этом примере становится видно, что пути становления парламентаризма в России были весьма извилисты и даже в рамках одной социальной группы существовали значительные противоречия по поводу политического устройства страны. Победу одержали сторонники сословной системы выборов, поскольку это позволяло дворянам быть более представленными в будущей Ауме, чем при других системах. В дальнейшем идеи этих проектов во многом послужили основой для консолидации дворянства и развития дворянского самоуправления. 


\section{ПРИМЕЧАНИЯ}

1 Занималась выработкой положений для будущего парламента. Названа по имени министра внутренних дел А. Г. Булыгина, возглавлявшего эту комиссию.

2 Законодательный акт, провозглашавший основные права и свободы и декларировавший создание парламента. Считается наивысшей точкой революции 1905-1907 гг.

\section{СПИСОК АИТЕРАТУРЫ}

Айнутдинова, А. М., Айнутдинов, Р. А. (2012) Российское общественно-политическое движение и политические организации в Казани (середина XIX - начало XX вв.) : науч.-справ. комплект. Казань : Яз. 252 с.

Боратынский, А. Н., Марковников, В. В. (б. г.) Отдельное мнение об организации представительства и выборного начала в России. Казань : [б. и.]. 16 с.

Журналы чрезвычайного Казанского губернского собрания дворянства 1-3 июня 1905 г., 16-20 февраля (1906). Казань : Тип. И. В. Ермолаевой, бывш. Ключникова. 84 с.

Записка подкомиссии по вопросу об организации народного представительства, основанной на принципе всеобщего и равного избирательного права (1905) // Труды комиссии, избранной чрезвычайным Казанским губернским собранием дворянства 12 марта 1905 г., по вопросу о народном представительстве. Казань : Типолит. И. Н. Харитонова. 127 с. С. 1-10.

Мельников, Н. А. (2008) 19 лет на земской службе (автобиографический очерк и воспоминания). Йошкар-Ола : [МарНИИЯАИ]. 342 с.

Миронова, Е. В. (2013) Аворянское самоуправление Казанской губернии в 1861-1917 гг. Казань : Ин-т истории им. Ш. Марджани АН РТ. 236 с.

Отчет казанской депутации, принимавшей участие на съезде губернских предводителей дворянства в Москве 24 апреля 1905 г., посланной согласно постановлению чрезвычайного Казанского губернского дворянского собрания 21 апреля и доложенной экстренному собранию 1 июня 1905 г. (б. г.) [б. м.] 22 с.

Постановления и краткий свод мнений комиссии по вопросу о народном представительстве (составлено А. А. Овчинниковым) (1905) // Труды комиссии, избранной чрезвычайным Казанским губернским собранием дворянства 12 марта 1905 г., по вопросу о народном представительстве. Казань : Типолит. И. Н. Харитонова. 127 с. С. 1-13.

Право всеобщего и равного голосования (Записка профес. А. В. Васильева) (1905)// Труды комиссии, избранной чрезвычайным Казанским губернским собранием дворянства 12 марта 1905 г., по вопросу о народном представительстве. Казань : Типолит. И. Н. Харитонова. 127 с. С. 1-7.

Проект организации народного представительства проф. В. В. Ивановского (1905)// Труды комиссии, избранной чрезвычайным Казанским губернским собранием дворянства 12 марта 1905 г., по вопросу о народном представительстве. Казань : Типолит. И. Н. Харитонова. 127 с. С. 1-14.

Протокол заседания подкомиссии по вопросу об образовании народного представительства на началах профессионально-классового (1905) // Труды комиссии, избранной чрезвычайным Казанским губернским собранием дворянства 12 марта 1905 г., по вопросу о народном представительстве. Казань : Типолит. И. Н. Харитонова. 127 с. разд. паг. С. 1-4.

Усманова, А. М. (2006) Аепутаты от Казанской губернии в Государственной думе России: 1906-1917. Казань : Татарское кн. изд-во. 494 с.

Хабибрахманова, А. В. (2006) Аеятельность политических партий в Казани в годы первой российской революции. Казань : Ин-т истории им. Ш. Марджани АН РТ. 200 с.

Аата поступления: 10.12.2015 2.

\section{POLITICAL PROJECTS OF KAZAN NOBILITY IN 1905 AS A NEW LEVEL OF THEIR SELF-CONSCIOUSNESS \\ YE. V. MIRONOVA}

(Sh. Marjani Institute of History, Academy of SCIENCES of the Republic of Tatarstan)

The article examines the part that members of the Assembly of nobility of Kazan gubernia took in elaborating projects of future political system of the Russian empire at the outbreak of the first 
Russian revolution in 1905. The current interest in the issues of parliamentarism and self-governance makes this historical episode still more topical.

A detailed study of the proceedings of the Assembly of nobility of Kazan gubernia and the works of the committee on popular representation helped us show that the Assembly of nobility began work on their project envisioning a popular representation body in order to allay the rising social unrest, especially among peasants of the gubernia. The project took two courses, exploring the opportunities offered by a suffrage system based on vocational and class representation, or by universal equal suffrage. The supporters of the latter approach tended to be more pro-democracy, but paid little attention to the size of constituencies and to the lack of the 'culture of democracy' among the general population. In the end, the committee members endorsed the former approach and voted to guarantee the right of legal initiative to the future representative body. In the wake of the All-Russia Congress of the nobility, A.N. Baratynsky and V.V. Markovnikov suggested an alternative solution which relied on the territorial authority of the Zemstvo, which was to elect members of the national representative body.

As seen from documentary evidence, the nobility as a corporation was far from unanimous and was actually split into several groups: moderate monarchists, right-wingers and liberals. Only the richest landed gentry were involved in the drafting of the projects. Their serious intention of calming down the unrest made them remain very conscious about providing solutions to both local and national issues. Although the Kazan project was never submitted to the Bulygin Committee, the work on it helped the local gentry get involved in national politics.

Our study has shown that the pathways of early Russian parliamentarism were far from straight. Even within a single one social group there was a good deal of contradiction on what shape the political system of Russia should take. As it is well-known, the supporters of estate-based suffrage won, which created the largest possible share of representation for the nobility in the future Duma. Later these projects and the ideas expressed therein formed the basis for consolidation of the nobility and the proliferation of their self-government.

Keywords: history of Russia; Russian empire; Kazan gubernia; Russian revolution of 1905-1907; nobility; State Duma; popular representation.

\section{REFERENCES}

Ainutdinova, L. M., Ainutdinov, R. A. (2012) Rossiiskoe obsbchestvenno-politicheskoe dvizhenie $i$ politicheskie organizatsii $v$ Kazani (seredina XIX - nacbalo XX vv.) : nauch.-sprav. komplekt [Social and political movement in Russia and political organizations in Kazan (mid-19th - early $20^{\text {th }}$ century): a handbook and reference]. Kazan, Iaz Publ. 252 p. (In Russ.).

Boratynskii, A. N. and Markovnikov, V. V. (s. a.) Otdel' noe mnenie ob organizatsii predstavitel'stva $i$ vybornogo nacbala $v$ Rossii [A dissenting opinion on setting up a representative and elective power in Russia]. Kazan, s. 1.16 p. (In Russ.).

Zhurnaly chrezvychainogo Kazanskogo gubernskogo sobraniia dvorianstva 1-3 iiunia $1905 \mathrm{~g}$., 16-20 fevralia (1906) [Proceedings of an emergency session of Assembly of nobility of Kazan gubernia, June 1-3, 1905, February 16-20, 1906]. Kazan, I. V. Ermolaeva. 84 p. (In Russ.).

Zapiska podkomissii po voprosu ob organizatsii narodnogo predstavitel'stva, osnovannoi na printsipe vseobshchego i ravnogo izbiratel'nogo prava (1905) [A memo by the subcommittee on setting up popular representation based on the principle of universal and equal suffrage]. In: Trudy komissii, izbrannoi chrezvychainym Kazanskim gubernskim sobraniem dvorianstva 12 marta 1905 g., po voprosu o narodnom predstavitel'stve [Works of the committee elected at the emergency session of Assembly of nobility of Kazan gubernia on March 12, 1905, on the issue of popular representation]. Kazan, I. N. Kharitonov. 127 p. Pp. 1-10. (Part 8) (In Russ.).

Mel'nikov, N. A. (2008) 19 let na zemskoi sluzbbe (avtobiograficheskii ocherk i vospominaniia) [19 years in the service of the zemstvo: An autobiographical sketch and memoirs]. Yoshkar-Ola, MarNIIIaLI. 342 p. (In Russ.)

Mironova, E. V. (2013) Dvorianskoe samoupravlenie Kazanskoi gubernii v 1861-1917 gg. [Selfgovernance of the nobility on Kazan gubernia, 1861-1917]. Kazan, Sh. Marjani Institute of History, Academy of Sciences of the Republic of Tatarstan. 236 p. (In Russ.). 
Otchet kazanskoi deputatsii, prinimavshei uchastie na s'ezde gubernskikb predvoditelei dvorianstva $v$ Moskve 24 aprelia 1905 g., poslannoi soglasno postanovleniiu chrezvychainogo Kazanskogo gubernskogo dvorianskogo sobraniia 21 aprelia $i$ dolozhennoi ekstrennomu sobraniiu 1 iiunia 1905 g. (s.a.) [s. 1.] [A report of the delegation from Kazan at the Congress of Marshals of gubernia nobility, April 24, 1905, sent to the congress in accordance with the decree of the emergency session of the Assembly of nobility of Kazan gubernia, April 21. Presented at the emergency session of June 1, 1905]. 22 p. (In Russ.).

Postanovleniia $i$ kratkii svod mnenii komissii po voprosu o narodnom predstavitel' stve (sostavleno A. A. Ovchinnikovym) (1905) [Resolutions and a concise compendium of opinions given at the committee on popular representation (compiled by A.A. Ovchinnikov)] In: Trudy komissii, izbrannoi chrezvychainym Kazanskim gubernskim sobraniem dvorianstva 12 marta 1905 g., po voprosu o narodnom predstavitel'stve [Works of the committee elected at the emergency session of Assembly of nobility of Kazan gubernia on March 12, 1905, on the issue of popular representation]. Kazan, I. N. Kharitonov. 127 p. Pp. 1-13. (Part 15) (In Russ.).

Pravo vseobshchego i ravnogo golosovaniia (Zapiska professora A. V. Vasil'eva) [The right of universal and equal suffrage: A memo by Professor A.V. Vasiliev] (1905). In: Trudy komissii, izbrannoi chrezvychainym Kazanskim gubernskim sobraniem dvorianstva 12 marta 1905 g., po voprosu o narodnom predstavitel'stve [Works of the committee elected at the emergency session of Assembly of nobility of Kazan gubernia on March 12, 1905, on the issue of popular representation]. Kazan, I. N. Kharitonov. 127 p. Pp. 1-7. (Part 9) (In Russ.).

Proekt organizatsii narodnogo predstavitel'stva prof. V. V. Ivanovskogo (1905) In: Trudy komissii, izbrannoi chrezvychainym Kazanskim gubernskim sobraniem dvorianstva 12 marta 1905 g., po voprosu o narodnom predstavitel'stve [Works of the committee elected at the emergency session of Assembly of nobility of Kazan gubernia on March 12, 1905, on the issue of popular representation]. Kazan, I. N. Kharitonov. 127 p. Pp. 1-14. (Part 4) (In Russ.).

Protokol zasedaniia podkomissii po voprosu ob obrazovanii narodnogo predstavitel'stva na nachalakh professional'no-klassovogo (1905) [Minutes of the session of the subcommittee on setting up popular representation in accordance with vocational and class-based suffrage]. In: Trudy komissii, izbrannoi chrezvychainym Kazanskim gubernskim sobraniem dvorianstva 12 marta 1905 g., po voprosu o narodnom predstavitel'stve [Works of the committee elected at the emergency session of Assembly of nobility of Kazan gubernia on March 12, 1905, on the issue of popular representation]. Kazan, I. N. Kharitonov. 127 p. Pp. 1-4. (Part 6). (In Russ.).

Usmanova, D. M. (2006) Deputaty ot Kazanskoi gubernii $v$ Gosudarstvennoi dume Rossii: 1906-1917 [Members of the Russian State Duma representing Kazan gubernia: 1906-1917]. Kazan, Tatarskoe knizhnoie izdatel'stvo. 494 p. (In Russ.).

Khabibrakhmanova, A. V. (2006) Deiatel'nost' politicheskikb partii v Kazani v gody pervoi rossiiskoi revoliutsii [Political parties in Kazan during the first Russian Revolution]. Kazan, Sh. Marjani Institute of History, Academy of Sciences of the Republic of Tatarstan. 200 p. (In Russ.)

Submission date: 10.12.2015.

Миронова Елена Валерьевна - кандидат исторических наук, старший научный сотрудник Центра изучения историко-культурного наследия народов Республики Татарстан Института истории им. Ш. Марджани Академии наук Республики Татарстан. Адрес: 420014, Россия, г. Казань, Кремль, 5-й подъезд. Тел: +7 (843) 292-84-82. Эл. адрес: Yelena.Mironova@yandex.ru

Mironova Yelena Valeryevna, Candidate of History, Senior Research Fellow, Center for the study of historical and cultural heritage of the peoples of Tatarstan, Sh. Marjani Institute of History, Academy of Sciences of the Republic of Tatarstan. Postal address: Pod'ezd 5, Kremlin, Kazan, Russian Federation 420014. Tel.: +7 (843) 292-84-82. E-mail: Yelena.Mironova@yandex.ru 